\title{
Upaya Meningkatkan Kompetensi Guru dalam Melaksanakan Keterampilan Dasar Mengajar Melalui Supervisi Akademik di SMA Negeri 25 Garut
}

\author{
Kustan Santana ${ }^{1}$, Dedi Mulyadi² \\ 1,2 Sekolah Menengah Atas Negeri 25 Garut, Indonesia \\ E-mail: kustansantana@gmail.com
}

\begin{abstract}
Article Info
Article History

Received: 2021-05-12

Revised: 2021-07-22

Published: 2021-08-18

Keywords:

Teacher;

Teaching;

Supervision.

Abstract

The purpose of this study was to determine the planning, implementation, assessment and follow-up in improving teacher competence in implementing basic teaching skills through academic supervision. Data collection techniques used are observation, interviews, and documentation. Data were analyzed using data reduction, data presentation, and drawing conclusions. The technique of checking the validity of the data is by triangulation of sources and techniques. The results of this study indicate that academic supervision at SMA Negeri 25 Garut carried out by the principal to the teacher has several stages, namely planning, implementation, assessment and followup. Academic supervision carried out at SMA Negeri 25 Garut by the principal runs according to the schedule that has been made at the beginning of the academic year. Each teacher is supervised at least twice, once in odd semesters and once in even semesters. So that every semester the teacher's teaching skills get better.
\end{abstract}

\begin{tabular}{l}
\hline Artikel Info \\
\hline Sejarah Artikel \\
Diterima: 2021-05-12 \\
Direvisi: 2021-07-22 \\
Dipublikasi: 2021-08-18
\end{tabular}

Kata kunci:

Guru;

Mengajar;

Supervisi.

\begin{abstract}
Abstrak
Tujuan penelitian ini adalah untuk mengetahui perencanaan, pelaksanaan, Penilaian dan tindak lanjut dalam meningkatkan kompetensi guru dalam melaksanakan keterampilan dasar mengajar melalui supervisi akademik. Teknik pengumpulan data yang digunakan adalah observasi, wawancara, dan dokumentasi. Data dianalisis menggunakan reduksi data, penyajian data, dan penarikan kesimpulan. Teknik pemeriksaan keabsahan data dengan triangulasi sumber dan teknik. Hasil penelitian ini menunjukkan bahwa supervisi akademik di SMA Negeri 25 Garut dilakukan kepala Sekolah kepada guru memiliki beberapa tahapan yaitu perencanaan, pelaksanaan, penilaian dan tindak lanjut. Supervisi akademik yang dilakukan di SMA Negeri 25 Garut oleh kepala Sekolah berjalan sesuai jadwal yang telah dibuat diawal tahun akademik. Masing-masing guru mendapat minimal dua kali disupervisi, satu kali di semester gasal dan satu kali di semester genap. Sehingga setiap semester keterampilan mengajar guru bertambah baik.
\end{abstract}

\section{PENDAHULUAN}

Pada era seperti saat ini, masalah pendidikan merupakan suatu hal yang sangat penting. Pendidikan merupakan kebutuhan yang sangat penting bagi setiap orang dalam rangka mengembangkan potensi diri, kecerdasan, keterampilan dan dapat membentuk kepribadian. Dengan pendidikan diharapkan seseorang dapat menggali informasi atau pengetahuan, melatih setiap bakatnya agar semakin terampil dan berkembang karakter pribadi seseorang. Peran pendidikan sangat strategis dalam upaya membangun generasi atau peserta didik yang berkualitas terutama dalam aspek karakter. Sehingga dibutuhkan seorang guru yang professional dalam rangka melaksanakan proses belajar mengajar yang berkualitas, Berdasar Undang-Undang Sisdiknas Nomor 20 Tahun 2003 menyatakan bahwa
Pendidikan adalah usaha sadar dan terencana untuk mewujudkan suasana belajar dan proses pembelajaran agar peserta didik secara aktif mengembangkan potensi dirinya untuk memiliki kekuatan spiritual keagamaan, pengendalian diri, kepribadian, kecerdasan, karakter mulia, serta keterampilan yang diperlukan dirinya, masyarakat, bangsa dan negara.

Pendidikan nasional bertujuan untuk mengembangkan segala potensi peserta didik agar menjadi manusia yang beriman dan bertaqwa kepada Tuhan yang Maha esa, berkarakter mulia, sehat, berilmu, cakap, kreatif, mandiri dan menjadi warga negara yang demokratis serta tanggungjawab. Berdasarkan fungsi dan tujuan pendidikan nasional tersebut, jelas bahwa pendidikan harus diselenggarakan secara sistematis guna mencapai tujuan tersebut. Peran Guru sebagai garda terdepan memiliki 
tanggung jawab yang sangat besar dalam rangka menyelenggarakan pembelajaran yang berkualitas.

Dalam upaya mengembangkan profesi dan kompetensi guru dalam rangka pelaksanaan tugas dan tanggung jawabnya secara profesional, dapat dilakukan melalui beberapa strategi atau model. Pengembangan tenaga kependidikan (guru) "dapat dilakukan dengan cara on the job training dan in service training". Pengembangan profesionalisasi guru dilakukan berdasarkan kebutuhan institusi, kelompok guru, maupun individu guru sendiri. Dari perspektif institusi, pengembangan guru dimaksudkan untuk merangsang, memelihara, dan meningkatkan kualitas staf dalam memecahkan masalahmasalah keorganisasian. Pengembangan guru berdasarkan kebutuhan institusi adalah penting, namun yang paling berperan penting adalah berdasar kebutuhan individu guru untuk menjalani proses profesionalisasi. Tuntutan untuk meningkatkan kompetensi guru bila tidak dibarengi dengan kemauan, tekad dan kreativitas yang tumbuh dari diri sendiri, maka akan sia-sia, tidak bermanfaat.

Setiap aktivitas besar maupun kecil yang tercapainya tergantung kepada beberapa orang diperlukan adanya koordinasi di dalam segala gerak langkah. Untuk mengkoordinasikan semua gerak langkah tersebut, seorang pemimpin harus berusaha mengetahui keseluruhan situasi di tempat dia memimpin dalam segala bidang. Usaha pimpinan untuk mengetahui situasi lingkungan tempat kerja dalam segala kegiatannya disebut supervisi. Menurut Mukhtar dan Iskandar (2009), bahwa supervisi adalah kepemimpinan instruksional yang menghubungkan perspektif terhadap perilaku, berfokus pada tujuan, berkontribusi terhadap tindakan organisasi, mengkoordinasikan interaksi, menyediakan perbaikan dan pemeliharaan program instruksional, dan menilai pencapaian tujuan.

Kegiatan supervisi tidak hanya dilakukan pada perusahaan pemerintah/swasta, tetapi juga diterapkan pada lembaga pendidikan yang tentunya tidak dapat melepaskan diri dari kegiatan supervisi. Dalam dunia pendidikan, supervisi tetap ada dan dibutuhkan. Bentuk supervisi yang dilaksanakan di sekolah dilakukan oleh kepala sekolah kepada guru. Supervisi dalam proses pendidikan menurut Hadari Nawawi yang dikutip oleh Kompri (2017) pada dasarnya pelayanan yang disediakan oleh pemimpin untuk membantu guru-guru agar semakin cakap sesuai dengan perkembangan ilmu pengetahuan pada umumnya dan ilmu pendidikan pada khususnya sehingga ia mampu meningkatkan efektivitas proses pembelajaran di sekolah. Menurut Ngalim Purwanto (2012) menyebutkan bahwa supervisi akademik adalah segala bantuan dari para pemimpin sekolah, yang tertuju kepada perkembangan kepemimpinan guru-guru dan personel sekolah lainnya di dalam mencapai tujuan-tujuan pendidikan. Berdasarkan pendapat ahli di atas, terdapat perbedaan terkait pengertian supervisi dalam hal pencapaiannya karena menurut Hadari kegiatan supervisi dapat meningkatkan efektivitas proses pembelajaran di sekolah.

Dalam rangka pelaksanaan supervis oleh Kepala Sekolah, hal ini memberikan manfaat bagi guru dalam meningkatkan kompetensi mengajar. Tujuan umum supervisi yakni memberikan segala bantuan seperti memperbaiki dan menyediakan kepada bawahan/orang yang disupervisi agar personil tersebut mampu meningkatkan kualitas kinerjanya, terutama dalam melaksanakan tugas, yaitu melaksanakan proses pembelajaran. Menurut Syaiful Sagala (2008), tujuan dari supervisi akademik adalah (a) Membantu guru-guru dalam mengembangkan proses belajarmengajar, (b) Membantu guruguru menterjemahkan kurikulum ke dalam bahasa belajar-mengajar, (c) Membantu guruguru mengembangkan staf sekolah. Berpijak pada tujuan tersebut, maka supervisi pendidikan menurut Arikuntro dalam Nasser (2021) mempunyai tiga fungsi, di antaranya sebagai berikut: a) Sebagai suatu kegiatan untuk meningkatkan mutu pendidikan, b) Sebagai pemicu atau penggerak terjadinya perubahan pada unsur-unsur yang terkait dengan pendidikan, dan c) Sebagai kegiatan dalam hal memimpin dan membimbing.

Supervisi ditujukan untuk menghasilkan perubahan manusia kearah yang dikehendaki, kemudian kegiatan supervisi harus disusun dalam suatu program yang merupakan kesatuan yang direncanakan dengan teliti dan ditujukan kepada perbaikan pembelajaran. Sebagai supervisor dalam melaksanakan supervisi hendaknya bertumpu pada prinsip supervisi agar supervisi yang dilaksanakan berdasarkan fakta dan data yang objektif serta dapat memenuhi fungsi dari supervisi tersebut. Menurut Rugaiyah dan Atike dalam Arifudin (2018) mengemukakan bahwa prinsip-prinsip supervisi adalah sebagai berikut: a) Prinsip ilmiah mencakup unsur-unsur sistematis dan objektif, yang memiliki arti dilaksanakan secara teratur, berencana dan 
kontinu (sistematis) serta data yang didapat berdasarkan pada observasi nyata, bukan tafsiran pribadi (objektif). b) Prinsip demokratis yaitu menjunjung tinggi asas musyawarah, dan memiliki jiwa kekeluargaan yang kuat serta sanggup menerima pendapat orang lain. c) Prinsip kooperatif yaitu seluruh staf sekolah dapat bekerja bersama, mengembangkan usaha bersama dalam menciptakan situasi belajar mengajar yang lebih baik. d) Prinsip konstruktif dan kreatif yaitu membina inisiatif guru serta mendorongnya untuk aktif menciptakan suasana di mana tiap orang merasa aman dan dapat mengembangkan potensi-potensinya.

Problem kualitas guru menjadi masalah yang urgen dalam pendidikan tingkat institusi, karena guru mempunyai kontak langsung dengan peserta didik dalam proses pembelajaran. Sehingga guru bertanggungjawab dalam keberhasilan proses dan hasil belajar peserta didik. Keterampilan utama dari seorang guru adalah melakukan penilaian dan pembinaan kepada siswa untuk secara terus-menerus meningkatkan kualitas proses pembelajaran yang dilaksanakan di kelas agar berdampak pada kualitas hasil belajar siswa. Untuk dapat mencapai kualitas tersebut guru diharapkan dapat melakukan pembelajaran yang didasarkan pada metode dan teknik yang tepat sesuai dengan kebutuhan siswa.

Kurangnya kemampuan guru dalam mengelola pembelajaran di kelas disebabkan oleh ketidak mampuan guru dalam melaksanakan peran dan fungsinya di sekolah. Padahal guru sangat menentukan terhadap keberhasilan pendidikan di sekolah, sedangkan guru itu sendiri perlu diberikan motivasi dan bimbingan baik dari Kepala Sekolah maupun Pengawas Sekolah untuk memperoleh hasil yang optimal, terutama sekali bagi guru yang mengalami permasalahan dalam melaksanakan tugasnya yaitu mendidik dan mengajar.

Berdasarkan masalah-masalah ini perlu dilakukan penelitian lebih lanjut supaya dapat di temukan data yang valid dan sekaligus dapat ditentukan alternatif pemecahannya. Sehingga penulis mengangkat judul "Upaya meningkatkan kompetensi guru dalam melaksanakan keterampilan dasar mengajar melalui supervisi akademik di SMA Negeri 25 Garut”.

\section{METODE PENELITIAN}

Penelitian upaya meningkatkan kompetensi guru dalam melaksanakan keterampilan dasar mengajar melalui supervisi akademik di SMA
Negeri 25 Garut menggunakan pendekatan kualitatif. Menurut (Yaniawati, 2017) pendekatan kualitatif yaitu penelitian yang diarahkan untuk pencapaian tujuan memperoleh penjelasan secara mendalam atas penerapan sebuah teori. Penelitian kualitatif memiliki karakteristik analisis tekstual atau dalam pandangan (Creswell, 2017) penelitian kualitatif merupakan penelitian interpretatif, yang di dalamnya peneliti terlibat dalam pengalaman yang berkelanjutan dan terus menerus dengan para partisipan. Adapun metode dalam penelitian ini adalah deskriptif analisis.

Dalam hal pengumpulan data yang diperoleh dari berbagai sumber, latar, dan beragam cara pada penelitian ini adalah melalui studi kepustakaan. Studi kepustakaan merupakan langkah awal dalam metode pengumpulan data. Studi pustaka merupakan metode pengumpulan data yang diarahkan kepada pencarian data dan informasi melalui dokumen-dokumen, baik dokumen tertulis, foto-foto, gambar, maupun dokumen elektronik yang dapat mendukung dalam proses penulisan. Menurut (Sugiyono, 2015), dokumen merupakan catatan peristiwa yang sudah berlalu. Dokumen bisa berbentuk gambar tulisan, gambar, atau karya-karya monumental dari seseorang. Hal itu, sejalan dengan pendapat (Creswell, 2017) bahwa dokumen-dokumen kualitatif (qualitatif document) bisa berupa dokumen publik (misalnya koran, makalah, laporan kantor) ataupun dokumen privat (mislanya buku harian, diari, surat, e-mail).

\section{HASIL DAN PEMBAHASAN}

Berdasarkan hasil penelitian bahwa upaya meningkatkan kompetensi guru dalam melaksanakan keterampilan dasar mengajar melalui supervisi akademik di SMA Negeri 25 Garut dilakukan dengan tahapan perencanaan, pelaksanaan, penilaian dan tindak lanjut dalam meningkatkan kompetensi guru dalam melaksanakan keterampilan dasar mengajar melalui supervisi akademik.

a) Perencanaan Meningkatkan Kompetensi Guru Dalam Melaksanakan Keterampilan Dasar Mengajar Melalui Supervisi Akademik

Perencanaan supervisi akademik di SMA Negeri 25 Garut dilakukan oleh kepala Sekolah di setiap awal tahun ajaran baru. Tahap perencanaan adalah tahap yang paling penting karena perencanaan dilakukan sebagai acuan formal dan targetan untuk 
pelaksanaan. Dalam konsep manajemen, perencanaan merupakan fungsi yang pertama. Salah satu tugas kepala sekolah adalah merencanakan supervisi akademik, sehingga kepala sekolah harus memilki kompetensi membuat perencanaan program supervisi akademik. Perenc-anaan supervisi akademik ini sangat penting karena dengan perencanaan yang baik, maka tujuan supervisi akademik akan dapat dicapai dan kita mudah mengukur ketercapaiannya. Perencanaan supervisi akademik ini sama keduduk-anya dengan perencanaan dalam fungsi manajemen pendidikan sehingga perlu dikuasai oleh supervisor yakni kepala sekolah.

b) Pelaksanaan Meningkatkan Kompetensi Guru Dalam Melaksanakan Keterampilan Dasar Mengajar Melalui Supervisi Akademik

Dalam pelaksanaan supervisi meningkatkan kompetensi guru dalam melaksanakan keterampilan dasar mengajar di SMA Negeri 25 Garut, pendekatan yang digunakan oleh kepala sekolah, sebenarnya sudah berjalan seperti yang diharapkan karena kepala sekolah membagi tugas supervisi dengan wakil kepala sekolah bidang akademik. Supervisi akademik yang dilakukan oleh kepala sekolah semua guru secara merata mendapatkan supervisi, oleh karena itu kepala sekolah sudah meningkatkan lagi frekuensi atau waktu untuk pelaksanaan supervisi seperti dengan melibatkan wakil kepala sekolah atau guru senior, hal ini terjadi karena banyaknya jumlah guru yang harus dibina. Kegiatan supervisi akademik kunjungan kelas, juga dilakukan pembinaan guru melalui kegiatan kelompok atau rapat rutin. Dalam pelaksanaan ada beberapa tahapan yaitu kepala Sekolah melakukan kegiatan Pra observasi sebelum memulai penilaian pada guru yang akan disupervisi. Dengan melihat hasil penilaian sebelumnya dan mempersiapkan berkas (instrumen penilaian) untuk observasi diharap pada supervisi yang akan dilaksanakan ada peningkatan. Melakukan observasi perencanaan dan pelaksanaan proses belajar mengajar. Kegiatan ini dilakukan oleh kepala Sekolah sekurang-kurangnya setiap sebulan 2 kali. Melakukan analisis hasil observasi serta yang terahir melakukam umpan balik hasil observasi melaksanakan supervisi. c) Penilaian Meningkatkan Kompetensi Guru Dalam Melaksanakan Keterampilan Dasar Mengajar Melalui Supervisi Akademik

Tahap penilaian supervisi akademik ini erat kaitannya dengan observasi perencanaan dan palaksanaan proses belajar mengajar. Dari hasil observasi perencanaan dan pelaksanaan proses belajar mengajar kepala Sekolah menilai apa-apa yang menjadi acuan supervisi akademik terkait ketrampilaan mengajar guru. Supervisi pendidikan mempunyai fungsi penilaian (evaluation) yaitu penilaian kinerja guru dengan jalan penelitian yaitu pengumpulan informasi dan fakta-fakta mengenai kinerja guru dengan cara melakukan penelitian. Kegiatan evaluasi dan research ini merupakan usaha perbaikan (improvement), sehingga berdasarkan data dan informasi yang diperoleh oleh supervisor dapat dilakukan perbaikan kinerja guru sebagaimana mestinya dan ahirnya dapat meningkatkan kualitas kinerja guru dalam melaksanakan tugas mengajar.

d) Tindak Lanjut Dalam Meningkatkan Kompetensi Guru Dalam Melaksanakan Keterampilan Dasar Mengajar Melalui Supervisi Akademik

Dalam tahap tindak lanjut supervisor harus menyusun program tindak lanjut dan melaksanakan program tindak lanjut supervisi akademik. Program tindak lanjut ini merupakan kebijakan yang dilakukan kepala Sekolah terkait hasil penilaian dan analisis hasil observasi perencanaan dan pelaksanaan proses belajar mengajar. Kemudian dituangkan dalam program tindak lanjut singkatnya kepala Sekolah membuat program dari hasil tersebut, guru mau diapakan. Pada pelaksanaan program tindak lanjut penilaian dan analisis hasil observasi perencanaan dan pelaksanaan proses belajar mengajar di SMA Negeri 25 Garut dilakukan dengan mengikuti berbagai pelatihan. Penggunaan beberapa teknik supervisi juga dilakukan dalam supervisi akademik di SMA Negeri 25 Garut yaitu supervisi individu melalui kunjungan kelas dan pertemuan individu. Dan supervisi kelompok melalui rapat, diskusi kelompok, penataran dan seminar. Hal ini juga untuk progam tindak lanjut supervisi akademik.

\section{SIMPULAN DAN SARAN}

\section{A. SIMPULAN}

Peran kepala sekolah dalam melaksanakan supervisi akademik tidak hanya masuk 
kedalam kelas melihat proses pembelajaran yang dilakukan guru, selain itu juga setiap pagi selalu mengontrol suasana seluruh lingkungan sekolah sampai dengan kebersihan kelas dan halaman. Supervisi akademik di SMA Negeri 25 Garut oleh kepala Sekolah sebagai supervisor. Supervisi akademik yang dilakukan di SMA Negeri 25 Garut oleh kepala Sekolah berjalan sesuai jadwal yang telah dibuat diawal tahun akademik. Masing masing guru mendapat minimal dua kali disupervisi, satu kali di semester gasal dan satu kali di semester genap. Sehingga diharap setiap semester keterampilan mengajar guru bertambah baik. Supervisi akademik ini memiliki beberapa tahapan, yang pertama perencanaan dilakukan oleh kepala Sekolah, kemudian observasi/pelaksanaan supervisi, penilaian dan analisis, serta melakukan tindak lanjut.

\section{B. SARAN}

Adapun saran yang dapat disampaikan berdasarkan pada hasil penelitian ini, diantaranya: (a) Bagi institusi, alangkah baiknya memberi fasilitas seperti mengadakan seminar atau loka karya sendiri, sehingga sesuai dengan kebutuhan guru yang ada di SMA Negeri 25 Garut terkait supervisi akademik, (b) Bagi Guru, hendaknya terus mengembangkan potensi yang dimiliki, sehingga keterampilan mengajarnya meningkat.

\section{DAFTAR RUJUKAN}

Arifudin, 0. (2018). Pengaruh Pelatihan Dan Motivasi Terhadap Produktivitas Kerja Tenaga Kependidikan STIT Rakeyan
Santang Karawang. MEA (Manajemen, Ekonomi, \& Akuntansi), 2(3), 209-218.

Creswell. (2017). Research Design Pendekatan Metode Kualitatif,. Kuantitatif, dan Campuran (Edisi ke-4). Yogyakarta: Pustaka Pelajar.

Kompri. (2017). Standardisasi Kompetensi Kepala Sekolah Pendekatan Teori untuk Praktik Profesional. Jakarta: Kencana.

Mukhtar dan Iskandar (2009). Orientasi Baru Supervisi Pendidikan. Jakarta: GP Press.

Nasser, A. A. (2021). Sistem Penerimaan Siswa Baru Berbasis Web Dalam Meningkatkan Mutu Siswa Di Era Pandemi. Biormatika: Jurnal Ilmiah Fakultas Keguruan Dan Ilmu Pendidikan, 7(1), 100-109.

Purwanto. (2012). Administrasi dan Supervisi Pendidikan. Bandung: Remaja Rosdakarya.

Sagala. (2008). Administrasi Pendidikan Kontemporer. Bandung: Alfabeta.

Sugiyono. (2015). Metode Penelitian Pendidikan (Pendekatan Kuantitatif,. Kualitatif dan R\&D). Bandung : CV. Alfabeta.

Undang-undang No. 20 Tahun 2003 Tentang Sistem Pendidikan Nasional. Jakarta: Sinar Grafika.

Yaniawati. (2017). Metodologi Penelitian. Bandung: PT. Refika Aditama. 